\title{
Determination of Physiochemical Qualities of Abattoir Effluent on Soil and Water in Gandu, Sokoto State
}

\author{
*Sumayya B. U, ${ }^{* *}$ Usman B. U** Aisha U. *Shahida A. ${ }^{* * *}$ Mohammad A., \\ "Yakubu M. S, and ${ }^{* * * *}$ Zainab M. \\ *Department of Natural Sciences, Sokoto State Polytechnic, Sokoto, **Sokoto State Vet. Clinic, Sokoto, \\ ***Ahmadu Bello Academy, Sokoto, ${ }^{* * * *}$ SSCOE Sokoto $* * * * H a f s a t A h m a d u$ Model Secondary School, Sokoto
}

\begin{abstract}
The effect of abattoir effluent on Gandu area of Sokoto State was examined for the physio-chemical properties during the rainy and dry season. The value $\mathrm{pH}$, phosphate, Nitrate, nitrogen contents dissolved oxygen (DO), BOD, potassium, percentage calcium magnesium and electrical conductivity was determined. The pH of well water DO, dissolved oxygen and nitrate all fall below the WHO tolerance level for drinking water quality standard these parameters shows that the water is not fit for human animal consumption.
\end{abstract}

Key Words; Pollution, Abattoir, waste-water-treatment, waterborne diseases

\section{Introduction}

Environmental problems have increased in geometric proportion over the last three decades with improper health practices being largely responsible for the gross pollution of the aquatic environment with concomitant increase in waterborne diseases, especially typhoid, diarrhea and dysentery (Atuanyaet.al., 2012)(Osibajo and Adie, 2007). Efforts have been geared towards curbing the menace of pollution around the world, particularly by the United Nations Organizations such as World Health Organization (WHO), and United Nations Environmental programs. There are many international conferences and protocols to this effect. Rio de Janeiro conference of 1992 was a major effort, collating previous environmental issues and bringing them to light (Oyesola, 1998).

Abattoirs, also known as slaughter houses are places where animals are butchered for food? Abattoir act (1998) defined abattoir as any premises used for or in connection with the slaughter of animal whose meat is intended for human consumption and include a slaughter house, but does not include a place situated on a farm (Bridges et al., 2000).

The continuous drive to increase meat production for the protein needs of the ever increasing world population has some problems attached. In many countries, pollution arises from activities in meat production as a result of failure in adhering to good manufacturing practices (GMP) and Good Hygiene Practices (GHP). Consideration is hardly given to safety practices during animal transport to the abattoir, their slaughter and their dressing. For example, during dressing the oesophagus of cattle and sheep should be sealed to prevent leakage of animal contents. These ineptitudes often lead to contamination from hide, hooves and content of alimentary tract during evisceration and negatively impact on the environment, including microbes in the soil and surface and ground water (Hinton et al., 2000).

A specific example of what happen is logging of contaminated water in the soil. In that situations, oxygen becomes less, available as an electron acceptor, promoting denitrifying bacteria to reduce available nitrate into gaseous nitrogen which enters the atmosphere with resultant negative effects. Also, anaerobic archaea (methanogens) may produce excessive methane at a higher rate than aerobic methane oxidizing bacteria (methanotrophs) could cope with, thus contributing to greenhouse effect and global warming. Increase in methane is of concern because it is five times more effective as a greenhouse gas than $\mathrm{CO}_{2}$ (Madigan et al., 2003). Leaching into groundwater is another concern, especially due to the recalcitrant nature of some contaminants (Lapyginaet al., 2002). The processes of absorption of water and trapping by fine sandy materials, clays and organic matter can filter out/trap microorganisms and pathogens and some dissolved organic matter during the passage of polluted water through the soil, thus reducing the microbial load. However, if there is a departure of the conditions from normalcy, beyond the carrying capacity of the natural process, the diversity of auto-chunos species could diminish while count of individual species that are able to survive may increase with the possibility of grave consequences on ground water (Atlas and Bartha, 1998).

Different methods of waste treatment have been developed, for reasons of public health and conservation, which results in the destruction of pathogens and the mineralization of the organic components of sewage prior to discharge. Anaerobic waste water treatment using granular sludge reactor is one of such methods (Liu et al., 2002). However, in Nigeria, like many developing countries, the control of the discharge of untreated wastes into the environment is still a problem, despite the establishment of Federal Environmental 
Protection Agency (FEPA) since 1998 (Adeyemo, 2003). Better inspection of abattoirs and strict enforcement of the law are needed to be able to reduce environmental contamination and related diseases. Attempts to control the hygienic conditions of slaughter houses should include physical assessment of the premises and animals themselves as those that are "visibly unacceptably dirty" or are affected by disease are not to be allowed for slaughter (Adeyemo, 2003).

\section{Material and Methods}

\section{Determination of Physio-chemical qualities}

The physic-chemical analysis carried out include $\mathrm{pH}$, Phosphate, nitrate, nitrogen content, dissolved oxygen, BOD, potassium, phosphorus, sodium magnesium particle size analysis, calcium and percentage sand silt and clay

\section{Results and Discussion}

The physicochemical properties of abattoir waste water during rainy and dry season showed the mean $\mathrm{pH}$ of the waste water to be 5.6 during the rainy season and 6.5 during the dry season. This showed that the $\mathrm{pH}$ of waste water was acidic and falls below the Federal Ministry of Environment (FMENV) effluent limit of 6-9, (Table 4.1), the mean $\mathrm{pH}$ of the contaminated soil was 7.63 for the dry season and 6.49 for the rainy season. The $\mathrm{pH}$ of rainy season and the dry season was neutral. A pH near 7.0 (neutral) plays a part in determining both the qualitative and quantitative abundance of micro flora (Edward, 1990, Federoret al., 1993;). It could be inferred then, that more hydrogen ion became available, lowering the $\mathrm{pH}$ value of contaminated soil and affecting the pattern of microbial population. The $\mathrm{pH}$ of the well water for the rainy season was 6.06 while for the dry season a mean $\mathrm{pH}$ of 5.6 was obtained. Both values fall below the standard

TABLE 4.1:

Physico-Chemical Properties Of Abattoir Waste Water During Rainy And Dry Seasons

\begin{tabular}{lcc}
\hline \multicolumn{1}{c}{ PARAMETERS } & RAINY & DRY \\
\hline $\mathrm{pH}$ & 5.15 & 6.15 \\
$\mathrm{E} . \mathrm{C}(\mu \mathrm{s} / \mathrm{cm})$ & $1-$ & $1-$ \\
$\mathrm{NO}_{3}(\mathrm{Mg} / \mathrm{l})$ & 10.764 & 9.001 \\
$\mathrm{P}(\mathrm{mg} / \mathrm{kg})$ & 0.143 & 0.111 \\
$\mathrm{~K}(\mathrm{mg} / \mathrm{kg})$ & 3.88 & 39.86 \\
$\mathrm{Na}(\mathrm{mg} / \mathrm{kg})$ & 22.62 & 7.5 \\
$\mathrm{Ca}(\%)$ & 0.29 & 0.56 \\
$\mathrm{Mg}(\%)$ & 1.30 & 0.15 \\
$\mathrm{DO}(\mathrm{mg} / \mathrm{l})$ & 13.89 & 13.23 \\
$\mathrm{BOD}(\mathrm{mg} / \mathrm{l})$ & 11.12 & 8.88 \\
\hline
\end{tabular}

KEY: Mg/kg: milligram per kilogram E.C Electrical Conductivity

TABLE 4.2:

Physico-Chemical Properties Of Abattoir Soil During Rainy And Dry Seasons

\begin{tabular}{ccc}
\hline PARAMETERS & RAINY & DRY \\
\hline $\mathrm{pH}$ & 6.49 & 7.63 \\
$\mathrm{E} . \mathrm{C}(\mu \mathrm{s} / \mathrm{cm})$ & 5438.92 & 733.44 \\
$\mathrm{NO}_{3}(\mathrm{mg} / \mathrm{l})$ & 0.0384 & 0.061 \\
$\mathrm{P}(\mathrm{mg} / \mathrm{kg})$ & 2.096 & 2.364 \\
$\mathrm{~K}(\mathrm{mg} / \mathrm{kg})$ & 78.4 & 9.575 \\
$\mathrm{Na}(\mathrm{mg} / \mathrm{kg})$ & 43.8 & 1.203 \\
$\mathrm{Ca}(\%)$ & 0.394 & 0.094 \\
$\mathrm{Mg}(\%)$ & 14.08 & 0.121 \\
$\mathrm{Sand}(\%)$ & 861.8 & 89.61 \\
$\mathrm{Silt}(\%)$ & 7.47 & 7.12 \\
$\mathrm{Clay}(\%)$ & 6.25 & 3.27 \\
\hline
\end{tabular}

KEY:Mg/kg: milligram per kilogram E.C Electrical Conductivity 
TABLE 4.3: PHYSICO-CHEMICAL PROPERTIES OF ABATTOIR WELL WATER DURING RAINY AND DRY SEASONS

\begin{tabular}{lcc}
\hline \multicolumn{1}{c}{ PARAMETERS } & RAINY & DRY \\
\hline $\mathrm{pH}$ & 6.06 & 5.6 \\
$\mathrm{E} . \mathrm{C}(\mu \mathrm{s} / \mathrm{cm})$ & 5376.2 & 1192.6 \\
$\mathrm{NO}_{3}(\mathrm{mg} / \mathrm{l})$ & 3.12 & 0.92 \\
$\mathrm{P}(\mathrm{mg} / \mathrm{kg})$ & 0.034 & 0.034 \\
$\mathrm{~K}(\mathrm{mg} / \mathrm{kg})$ & 26.94 & 3.26 \\
$\mathrm{Na}(\mathrm{mg} / \mathrm{kg})$ & 5.98 & 1.44 \\
$\mathrm{Ca}(\%)$ & 2.32 & 0.47 \\
$\mathrm{BOD}(\mathrm{mg} / \mathrm{l})$ & 7.3 & 0.94 \\
$\mathrm{DO}(\mathrm{mg} / \mathrm{l})$ & 10.95 & 4.68 \\
$\mathrm{CI}(\mathrm{mg} / \mathrm{l})$ & 24.24 & 1.4 \\
\hline
\end{tabular}

KEY:Mg/kg: milligram per kilogramE.C Electrical Conductivity

limit(Federoret al., 1993).The $\mathrm{pH}$ obtained for the well water is not within the WHO pH tolerance level for drinking water quality standards (WHO 1996). This is as a result of washing of abattoir waste water by rain and human activities, which is in conformity with Sanjodoyinet al (1992) they reported that wells in the vicinity of abattoirs, which serve as sources of water to the abattoir dwellers is being polluted by effluent from the abattoir and constitute health risk to the butchers and users of the wells.

The Dissolved Oxygen (DO) value obtained for the waste water in the rainy season varies between 6.6 $-21.6 \mathrm{mg} / \mathrm{l}$ and $6.8-22.7 \mathrm{mg} / \mathrm{l}$ for the dry season. The standard for sustaining aquatic life is stipulated at $5 \mathrm{mg} / \mathrm{l}$ a concentration below this value adversely affects aquatic life, while concentration below $2 \mathrm{mgk}$ may lead to death of fishes (Chapman, 1992). This value is within the limit of the World Health Organization. The mean DO of the well water for the rainy and dry seasons, $3.1-3.9 \mathrm{mg} / \mathrm{l}$ and $4.2-5.3 \mathrm{mg} / \mathrm{l}$ respectively which was below the standard limit of $5 \mathrm{mg} / \mathrm{l}$ set by the WHO tolerance level for drinking water quality standard.

Mean phosphate values for wastewater, soil and well water are $0.14 \mathrm{mg} / \mathrm{l}, 2.096 \mathrm{mg} / \mathrm{kg}$ and $0.03 \mathrm{mg} / \mathrm{l}$ respectively in the rainy season while the dry season recorded a mean value of $0.11 \mathrm{mg} / \mathrm{l}, 2.36 \mathrm{mg} / \mathrm{kg}$ and $0.03 \mathrm{mg} / \mathrm{l}$, all falling within the standard limit of 0.1 . The reason could be that no detergent was used to wash the roasted carcass. Nitrate value for waste water ranging from $9.72-12.24 \mathrm{mg} / \mathrm{l}$ during the rainy season was high, while in the well water the range of $0.8-5.4 \mathrm{mg} / \mathrm{l}$ in the rainy season and $0.7-1.0 \mathrm{mg} / \mathrm{lin}$ the dry season was quite acceptable compared with WHO and Nigerian water quality standard of 0.5 and 5 as reported by WHO, (1996).

The nitrogen content of the abattoir soil ranged from $0.049-0.07 \%$ in the dry season and $0.028-$ $0.053 \%$. This was also below the WHO (1996) standards. The abattoir effluent appeared to have influenced, to some extent the total nitrogen content of the polluted soils. A substantial amount of the nitrogen may have been lost through volatilization because of the pungent smell that was emanating from the effluent as reported by Prasad and Datta(1979).

\section{References}

[1]. Abattoir Acts (1998) Retrieved 2003 from http//www. Irishstatutebook.i.e/1988/en/act/pub/0008/index.hhtml.

[2]. Adeyemo, O.K. (2003). Consequences of pollution and degradation of Nigeria aquatic environment on fisheries resources.The environmentalist 23:297-306.

[3]. Adesomoye, A.O., Opera, B.O and Makinde, S.C.O. (2006). Microbial content of abattoir wastewater and it contaminated soil in Lagos, Nigeria. African Journal of Biotechnology5(20):1963-1968.

[4]. Alonge, D. O. (1991).TEXTBOOK OF MEAT HYGIENE IN THE TROPICS Farm COE cPress, Ibadan, Nigeria p 58.

[5]. Atlas, R.M., Bartha, R. (1998). BIOGEOCHEMICAL CYCLING: CARBON, NITROGEN AND OXYGEN IN MICROBIAL ECOLOGY: FUNDAMENTALS AND APPLICATIONS $4^{\text {th }}$ Edition. Benjamin/Cummings Science Publishing, California, pp. 386 -410 .

[6]. Atlas, R. M. and Bartha, R. (2007) MICROBIAL ECOLOGY; FUNDAMENTALS AND APPLICATIONS,BanjaminKumings Publishing Company Inc.

[7]. AtuanyaE.I,Nwogu N. A and Akpor E.A, (2012) .Effluent Qualities of Government and Private . Abattoirs and their Effects on IkpobaRiver, ．Benin City, Edo State, NigeriaAdvances in ～～Biological Research 6 (5): 196-201, 2012

[8]. ISSN 1992-0067

[9]. Bala, J. D. (2006) Occurrence of Facecal Coliforms in Water Sources in Jimeta - Yola, Nigeria. Journal of Environmental Sciences 10(2): $64-69$

[10]. Bridges, O., Bridges, J.W., Potter, I.F. (2000). A generic comparison of the airborne risks to human health from kindfill and incinerator disposal of municipal solid waste.The environmentalist 18: $661-671$.

[11]. Chapman, D. (1992). Water Quality Assessments.A Guide to the use of Biota, Sediments and Water in Environmental Monitoring. UNESCO/WHO/UNEP, Chapman and Hall, London, p $371-460$. 
[12]. Edwards, C. (1990) MICROBIOLOGY OF EXTREME ENVIRONMENTS. $2^{\text {nd }}$ Edition Open University Press, Milton Keynes, p. 22

[13]. Ezeama, C.F., Nwamkpa, F (2002). Studies on the Longitudinal Profile of the Bacteriological Quality of Aba River Nigeria Global J. Pure Appl. Sci. 8(4): $469-473$.

[14]. Ezeronye, O. U and Ubalua, A. O (2005) Studies in the Effect of Abattoir and Industrial Effluent on the Heavy Metals and Microbial Quality of Aba River in Nigeria.African Journal of Biotechnology, 4(3): 266 - 272.

[15]. Federov AY, Volchenko EV, Korzhenevich VI, Singirtsevc IN, Krestyaninor VY (1993). A Polysubstrate Strain that Degrades Waste Water Components of Phenol Production.J. appl. Biochen, Microbial, 29: 532 - 536.

[16]. Hinton, M., H., Meud, G.C., Rowlings, C. (2000).Microbiology Control in the meat Industry. Flair Flow Europe Technical Manual F. Fe 339A100 May 2000, pp. 4-12 (www.exp.ie/flair.htm)

[17]. Lapygina, E.V., Lysak, L.V., Zvyaginstev, D.G., (2002). Tolerance of Soil bacterial complexes to Salt shock.Microbial.71:143 147.

[18]. Madigan, M.T., Martinko, J.M., Parker, J. (2003). Brock biology of Microorganism.International edn. Prentice Hall Intern Ltd, London, pp. $1020-1040$.

[19]. Matthew, O. (1998). Microbes Humans and animals.Poly graphic Ventures, Ibadan. $1^{\text {st }}$ Ed. Pp. 3 - 4.

[20]. Osibajo, O. and Adie, (2007).Impact of effluent from Bodija abattoir on the physico-chemical parameters of Oshinkaye Stream in Ibadan City, Nigeria. Afr. J. Biotech., 6 (15): 1806-1811.

[21]. Oyeleke, S. B. and Manga, S. B. (2008).Essentials of Laboratory Practical in Microbiology.Tobest publisher.Minna, Nigeria. Pp. $20-80$.

[22]. Oyesola D. (1998) Protection and control of the environment: major regimes in: Politics of International environmental regulations. Daily Graphic Publications, Ibadan, Nigeria, pp. 62-92.

[23]. Prasad, R and De Datta, S.U (1979). Increasing Fertilizer Nitrogen Efficiency in Wet Land Rice (pp. 465 - 484) Rice Research Institute, Report, Manilla, Philippines.

[24]. Sangodoyin, A. Y., Agbawhe, O. M., (1992). Environmental Study on Surface and Ground Water Pollutants from Abattoir Effluents Bioresearch Technology 41(2):193-200.

[25]. Liu, Y., Xu, H., Show. K., Tay J. (2002) Anaerobic granulation technology free wastewater treatment world microbio. Biotechnol18:99- 133.

[26]. World Health Organization (WHO, 1996). Guidelines for Drinking water Quality. Health Criteria and Other Quality Health Criteria and other supporting information.Publication of WHO Geneva.pp 302-441. 